Keio J. Med. 29: 141-151, 1980

\title{
STUDY ON BLOOD LEVELS OF LUTEINIZING HORMONE BETA SUBUNIT AND LH-RELEASING FACTOR IN PREGNANT WOMEN
}

\author{
TSUNEHISA MAKINO, MITSUTOSHI IWASHITA, AKIHIKO NAKAYAMA, \\ TSUNEO YOKOKURA, LIN HORYO, MASATAKE SAKAI, \\ MASAYOSHI ARISAWA, KENICHI IMAGAWA* \\ and RIHACHI IIZUKA \\ Department of Obstetrics and Gynecology, School of Medicine, \\ Keio University, Tokyo, Japan \\ *Otsuka Assay Laboratories, Tokushima-shi
}

(Received for publication July 21, 1980)

\begin{abstract}
The hypothalamo-pituitary function during pregnancy was investigated by analysing blood levels of Luteinizing Hormone Releasing Factor (LH-RF) and LH-beta subunit. A specific and sensitive radioimmunoassay which can detect as small as 300 femtogram of LH-RF per tube was developed. This revealed that plasma LH-RF concentrations were $1.0 \pm 0.14 \mathrm{pg} / \mathrm{ml}$ (mean \pm S.E.) at follicular phase $(n=17)$ and $1.1 \pm 0.19 \mathrm{pg} / \mathrm{ml}$ at luteal phase $(n=8)$, whereas LH-RH was detectable in only 3 out of 20 samples from pregnant women and mean values were significantly decreased to $0.4 \pm 0.02 \mathrm{pg} / \mathrm{ml}$. Similarly serum $\mathrm{hLH}$ beta levels were $438.56 \pm 49.30 \mathrm{ng} / \mathrm{ml}$ at follicular phase $(\mathrm{n}=33), 632.71 \pm 75.09 \mathrm{ng} / \mathrm{ml}$ at mid-cycle $(\mathrm{n}=21)$ and $258.55 \pm 46.84 \mathrm{ng} / \mathrm{ml}$ at luteal phase $(n=20)$, respectively. The levels of this hormone were also markedly decreased to $11.81 \pm 0.95 \mathrm{ng} / \mathrm{ml}$ during pregnancy $(\mathrm{n}=129)$.

The data indicate that the hypothalamo-pituitary function, in terms of the hormones measured in this study, is lowered during pregnancy, presumably by the influences of placental hormones.
\end{abstract}

Normal pregnancy is maintained on a hormonal architecture of both the hypothalamo-hypophyseal-ovarian and the feto-placental system. In human subjects, luteal function of both the luteinized ovaries and the placenta during pregnancy can be maintained mainly by the stimulation of chorionic gonadotropin (hCG). Pituitary luteinizing hormone $(\mathrm{LH})$ in women is suggested to play some 
role at early stage of gestation. In contrast, $\mathrm{Raj}^{1}$ and $\mathrm{we}^{2}$ reported that $\mathrm{LH}$ has a main luteotropic factor up to the middle stage of pregnancy in the rats. We are, therefore, interested in how the higher center for human luteal function keeps its hormonal function through the course of pregnancy after the placental function is established as luteotropic endocrine organ. It is well known that anterior pituitary function is under hypothalamic control and its hormonal agents, called as releasing factors or hormones, are released into the portal vessels of the median eminence from the nerve endings of the hypothalamic tracts. ${ }^{3}$

Since little is known on the alteration of blood levels of hypothalamic LHreleasing factor ( $\mathrm{LH}-\mathrm{RF}$ ) and $\mathrm{LH}$ in pregnant women, we have utilized specific LH-RF and LH-beta radioimmunoassays to investigate the hypothalamo-pituitary function during human pregnancy.

\section{MATERIALS AND METHODS}

Subjects: Seventy four mature women with 28-30 days regular menstrual cycle and 128 pregnant women who also showed 28-30 days menstrual cycle before pregnancy were subjects for this study.

LH-RF Radioimmunoassay: A highly specific and potent antiserum to LH$\mathrm{RF}$ was generated in the rabbits by a slight modification of the method reported previously. ${ }^{4,5}$ Synthetic LH-RF (Sankyo Pharmaceutical Co., Ltd., Tokyo) was conjugated to bovine serum albumin (BSA) or human serum albumin (HSA) by utilizing l-ethyl-3 (3-dimethyl-aminopropyl) carbodiimide- $\mathrm{HCl}$ (EDC, Otto Chemical Co., Ltd., U.S.A.) as coupling agent. After dialysis against phosphatebuffered saline at $\mathrm{pH} 7.3$, the polypeptidyl-protein was used as an antigen after emulsification with Freund's complete adjuvant and was used to immunize the female rabbits. After examination for the specificity of the antiserum on immunocross-reactivity with other hypothalamic and pituitary peptides in vitro, a double antibody radioimmunoassay was performed for plasma LH-RF. Prior to the assay, each plasma sample was treated with a drop of $1 \mathrm{M}$ acetic acid and 3 times volumes of $70 \%$ methanol. The tube was mixed for a few minutes and then centrifuged for 30 minutes. The supernatant was decanted into a vial and evaporated to dryness in a water bath at $40^{\circ} \mathrm{C}$. The dry residue was dissolved in $0.6 \mathrm{ml}$ assay diluent and $0.2 \mathrm{ml}$ of the extract in duplicate were used for assay. In order to obtain higher sensitivity in the assay, the radioiodination of the hormone and assay time were re-evaluated. By using highly specific ${ }^{125}$ I-LH-RF (approximately $1,200 \mu \mathrm{Ci} / \mu \mathrm{g}$ ) through a carboxymethyl cellulose (CMC) column and pre-incubation procedure, a linear dose-response curve was obtained between $300 \mathrm{fg}$ and $100 \mathrm{pg}$ of $\mathrm{LH}-\mathrm{RF} /$ tube, which is adequate to measure the peripheral 
blood level of LH-RF.

Radioimmunoassay for Human $\mathrm{LH}(\mathrm{hLH})$ - and Chorionic Gonadotropin (hCG)-beta Subunit: hLH-beta and hCG-beta in sera were measured by double antibody radioimmunoassays. Purified hLH-beta (NIAMDD hLH-beta subunit) and hCG-beta (NIAMDD hCG CR-115 beta) were labeled with $1.0-1.5 \mathrm{mCi}$ of ${ }^{125} \mathrm{I}-\mathrm{Na}$. Serum $\mathrm{LH}$ and hCG values are also expressed in terms of $\mathrm{ng} / \mathrm{ml}$ of $\mathrm{hLH}$ and HCG. In other 52 samples plasma LH was measured by another radioimmunoassay and values are expressed as $\mathrm{mIU}$ of $\mathrm{LH} / \mathrm{ml}$ plasma.

\section{RESULTS}

The iodination of LH-RF was performed by the slightly modified procedure of Hunter and Greenwood's chloramine-T method, ${ }^{6}$ then ${ }^{125}$ I-labeled LH-RF was purified by ion exchange chromatography on CMC column. After free ${ }^{125}$ I was eluted with $0.002 \mathrm{M}$ ammonium acetate buffer, ${ }^{125} \mathrm{I}-\mathrm{L}$ H-RF was eluted with

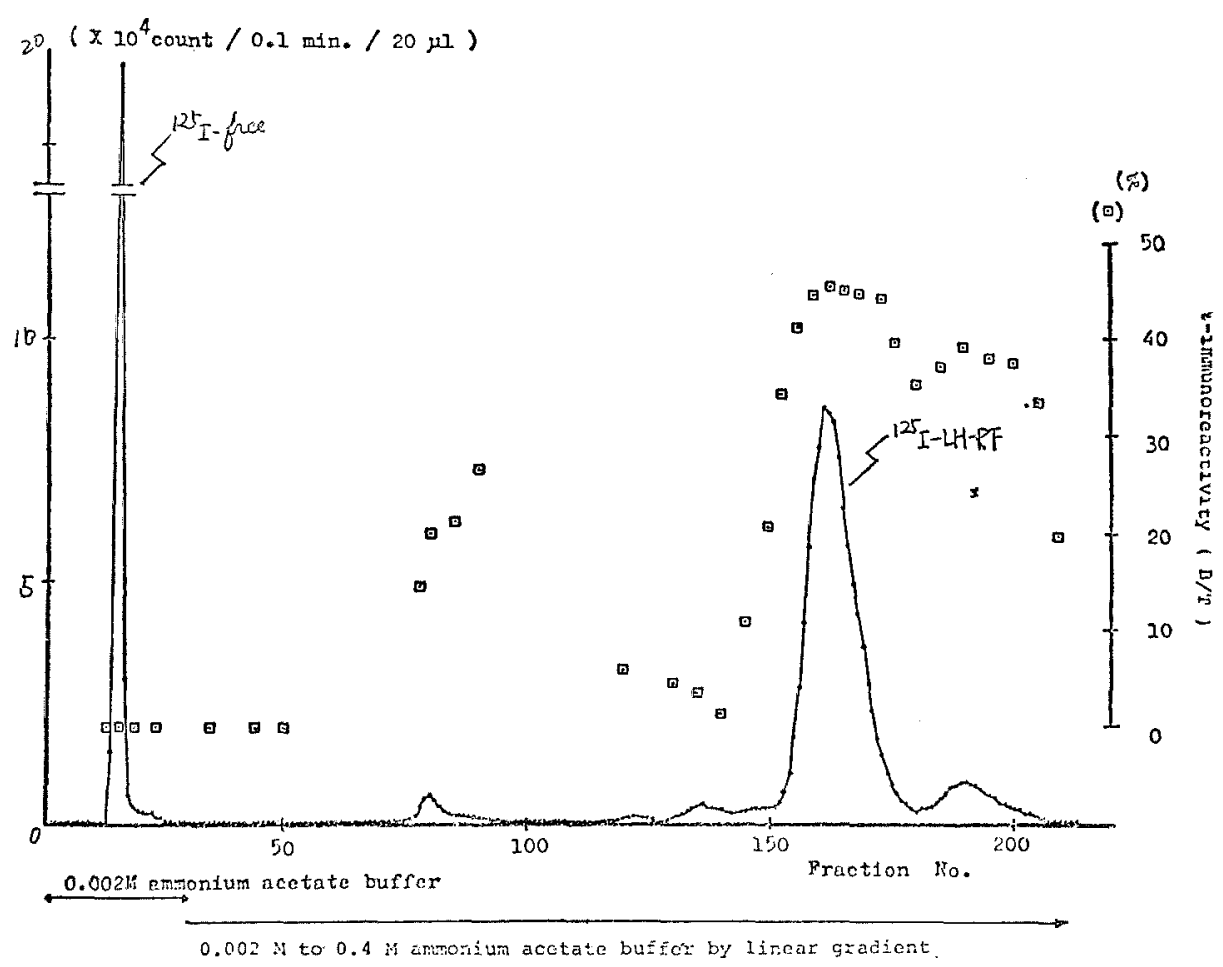

Fig. 1 Purification of ${ }^{125}$ I-labeled LH-RF by ion exchange chromatography on CMC. 

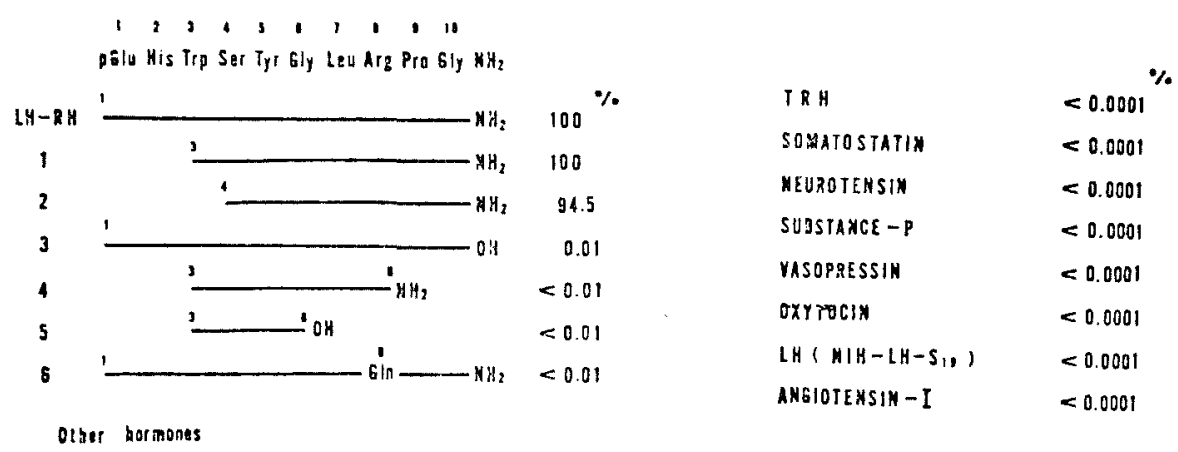

Fig. 2 Crossreactivity of antiserum to LH-RF analogs and other hormones.

$0.002 \mathrm{M}$ to $0.4 \mathrm{M}$ ammonium acetate buffer by linear gradient and relatively high specific activity of $1,200 \mu \mathrm{Ci} / \mu \mathrm{g}$ was obtained by this chromatography (Fig. 1). Several peptides were tested for their abilities to displace 125I-LH-RF from the antibody. The antiserum obtained from immunized female rabbits showed less than $0.0001 \%$ immuno-cross-reactivity with pituitary gonadotropins, substance $P$, arginine and lysine vasopressin, oxytocine, TRF and somatostatin, although the antiserum reacted with synthetic LH-RF and several analogs of the decapeptide with carboxy terminal (Fig. 2). To obtain more sensitive radioimmunoassay for LH-RF, so-called delayed assay (pre-incubation) were tested and compared with an ordinary assay system according to the assay schedules (Table 1). The most sensitive dose response curve was obtained using 48 hours preincubation followed by 6 hours incubation with labeled antigen indicated in Fig. 3.

By applying highly specific ${ }^{125} \mathrm{I}-\mathrm{LH}-\mathrm{RF}$ and the delayed assay system for measurement of plasma LH-RF, blood levels of LH-RF were examined in pregnant and non-pregnant women. Regarding to distribution of plasma LH-RF values in pregnant and non-pregnant women, LH-RF were all detectable in the plasma of non-pregnant women, although the values were varied between 0.3 and $1.9 \mathrm{pg} / \mathrm{ml}$ (Fig. 4). In contrast only 3 out of 20 samples from pregnant women showed detectable levels. Plasma levels of LH-RF at follicular and luteal phase in the non-pregnant women were $1.0 \pm 0.14 \mathrm{pg} / \mathrm{ml}$ (mean \pm S.E.) and $1.2 \pm 0.19 \mathrm{pg} / \mathrm{ml}$, respectively (Table 2 ), whereas the values in pregnant women were $0.4 \pm 0.02 \mathrm{pg} / \mathrm{ml}$. Of interest plasma $L H-R F$ levels increased significantly to $1.7 \pm 0.42 \mathrm{pg} / \mathrm{ml}$ in menopausal women. However serum $\mathrm{hLH}$-beta levels were 
Table 1

Radioimmunoassay procedure for $L H-R F$ for plasma samples

\begin{tabular}{|c|c|c|}
\hline \multicolumn{2}{|c|}{$\begin{array}{l}\text { Standard diluent* } \\
\text { Anti LN-RF serum } \\
\text { LN-RF standard saln. or sample }\end{array}$} & $\begin{array}{l}0.2 \mathrm{mI} \\
0.1 \\
0.2\end{array}$ \\
\hline \multicolumn{3}{|c|}{ Incubate for 48 hours at $4^{\circ} \mathrm{C}$} \\
\hline \multicolumn{2}{|l|}{${ }^{125}$ I-LH-RF $7000 \mathrm{cpm}$} & $0.1 \mathrm{ml}$ \\
\hline \multicolumn{3}{|c|}{ Incubate for 6 hours at $4^{\circ} \mathrm{C}$} \\
\hline \multicolumn{2}{|c|}{$\begin{array}{l}\text { Normal rabbit serum } \\
\text { Goat anti-rabbit } \gamma \text {-globulin serum }\end{array}$} & $\begin{array}{l}0.1 \mathrm{ml} \\
0.1\end{array}$ \\
\hline \multicolumn{3}{|c|}{$\begin{array}{l}\text { Incubate for } 24 \text { hours at } 4^{\circ} \mathrm{C} \\
\text { trifuge for } 30 \text { min. at } 4^{\circ} \mathrm{C} \\
\text { nt both precipitable (bound and super- } \\
\text { ant (free) by automatic gamma counter }\end{array}$} \\
\hline buffer & $\begin{array}{ll}0.15 \mathrm{M} \mathrm{NaCl} \\
0.05 \mathrm{M} & \mathrm{EDT} \\
0.1 \% & \mathrm{BSA} \\
0.01 \% & \mathrm{NaN}_{3}\end{array}$ & \\
\hline
\end{tabular}
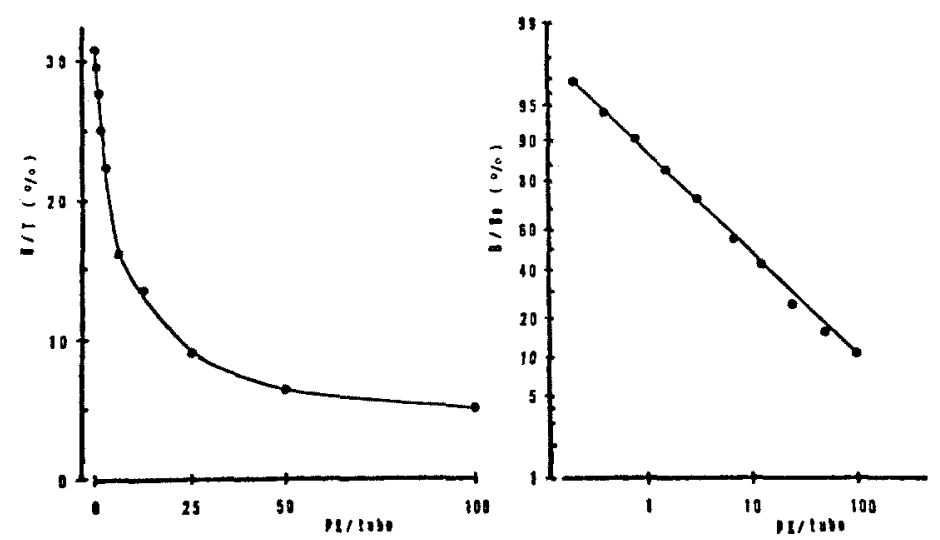

Fig. 3 Standard curve for synthetic LH-RF. 


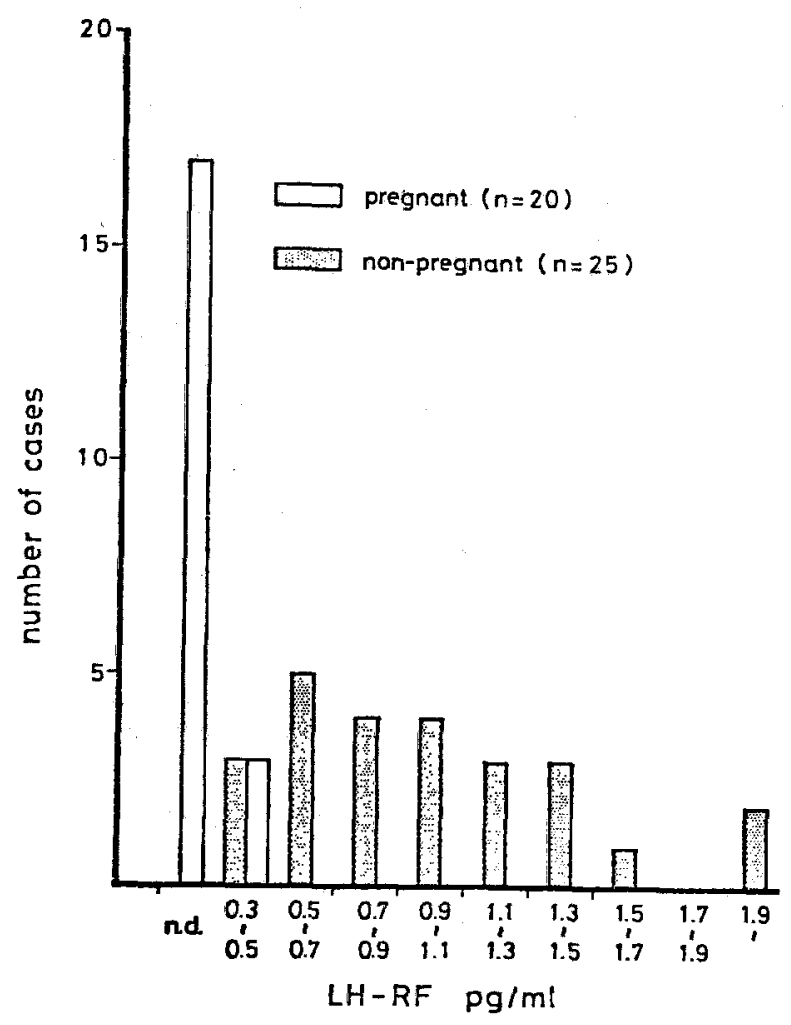

Fig. 4 Distribution of plasma LH-RF values in pregant and non-pregnant women.

Table 2

Plasma levels of $L H-R F, L H$ and FSH

\begin{tabular}{l|c|c|c|c}
\hline \multicolumn{1}{c|}{ Subject } & No. of cases & LH-RF pg/ml & LH mlU/ml & \multicolumn{1}{|c}{ FSH $\mathrm{mlU} / \mathrm{ml}$} \\
\hline Follicular phase & 17 & $0.99 \pm 0.14$ & $16.95 \pm 3.13$ & $10.14 \pm 0.59$ \\
Luteal phase & 8 & $1.16 \pm 0.19$ & $13.99 \pm 3.52$ & $9.33 \pm 1.65$ \\
Pregnancy & 20 & $0.35 \pm 0.02$ & $456.54 \pm 9.64$ & $4.04 \pm 0.29$ \\
Menopause & 7 & $1.65 \pm 0.42$ & $77.6 \pm 18.57$ & $99.53 \pm 10.55$ \\
\hline
\end{tabular}


Table 3

Serum $h L H$-beta concentrations through the pregnant periods

\begin{tabular}{c|c|c}
\hline \hline Weeks of pregnancy & No. of Samples & $\begin{array}{c}\text { Serum hLH- } \beta \text { levels } \\
\text { mean } \pm \text { S.E. (ng/ml serum) }\end{array}$ \\
\hline $6 \sim 10$ & 16 & $14.41 \pm 2.58$ \\
$10 \sim 15$ & 30 & $9.82 \pm 1.70$ \\
$16 \sim 20$ & 10 & $10.05 \pm 2.78$ \\
$21 \sim 25$ & 8 & $10.54 \pm 2.65$ \\
$26 \sim 30$ & 11 & $14.55 \pm 3.58$ \\
$31 \sim 35$ & 34 & $12.96 \pm 2.50$ \\
$36 \sim 40$ & 19 & $10.86 \pm 1.63$ \\
\hline
\end{tabular}

Table 4

Serum hLH-beta levels through the menstrual cycle

\begin{tabular}{c|c|c}
\hline \hline Days of menstraul cycle & No. of Samples & $\begin{array}{c}\text { Serum } h L H-\beta \text { levels } \\
\text { mean } \pm \text { S.E. (ng/ml serum) }\end{array}$ \\
\hline $1 \sim 4$ & 8 & $296.25 \pm 79.44$ \\
$5 \sim 8$ & 11 & $414.45 \pm 81.18$ \\
$9 \sim 12$ & 14 & $517.86 \pm 81.10$ \\
$13 \sim 16$ & 21 & $632.71 \pm 75.09$ \\
$17 \sim 20$ & 0 & \\
$21 \sim 24$ & 12 & $246.25 \pm 52.75$ \\
$25 \sim 28$ & 8 & $277.00 \pm 90.82$ \\
\hline
\end{tabular}

significantly reduced during pregnancy (Table 3) as compared to the levels in normal menstrual cycle (Table 4). In contrast, serum hCG concentration in 112 pregnant women increased acutely around 10 weeks of gestation, gradually decreased after 15 weeks. The values fluctuated between 500 and $1,000 \mathrm{ng} / \mathrm{ml}$ and slightly increased during 34-38 weeks (Fig. 5).

\section{COMMENTS}

It is well documented that the pituitary gland increases in size during pregnancy. This endocrine gland is also markedly enlarged in multipara women. However the function of the hypothalamo-hypophyseal axis in terms of pituitary gonadotropin secretion during pregnancy is not clearly understood. It has been reported that in some species hypophysectomy at mid-pregnancy or later does 


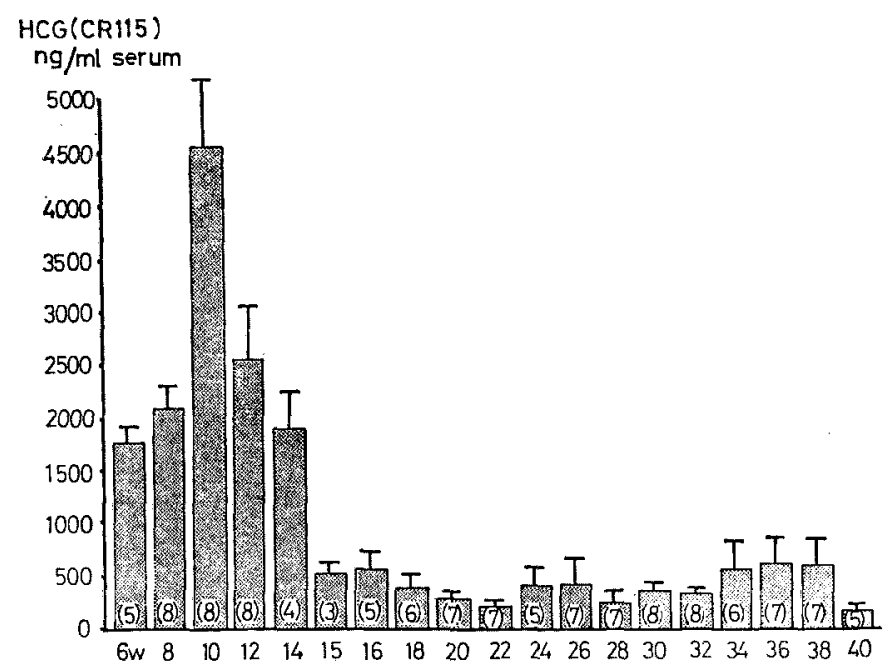

Fig. 5 Serum hCG concentration of 112 pregnant women.

not interrupt continuation of pregnancy whereas in other species abortion occurs. Smith ${ }^{7}$ reported that the pituitary is not necessary for the maintenance or successful termination of gestation in the rhesus monkeys. He hypophysectomized 20 pregnant rhesus monkeys and 10 of the animals successfully went to term. According to his report, the length of gestation was normal except for one case and the living babies were healthy, though the lactation was of brief duration. Furthermore Little, ${ }^{9}$ documented an interesting case of hypophysectomy in a pregnant woman with metastatic cancer of the breast at 26th weeks of pregnancy. Although this patient required replacement therapy of cortisone, thyroid and pitressin for the duration of pregnancy after complete hypophysectomy, it was reported that a normal 5-pound infant was delivered at 35 weeks. All these reports indicate that pregnancy may continue without maternal pituitary gland. Therefore it was of interest to investigate the function of the hypothalamopituitary axis during pregnancy in human subjects.

In 1972 Jutisz and Kerdelhué first reported a radioimmunoassay for LH-RF. ${ }^{9}$ Since then this assay method has been applied to the measurement of LH-RF in peripheral plasma of many species, ${ }^{10,11,12}$ although there have been some disaccord in absolute values of this hypothalamic peptide in the peripheral blood. More recently Aksel and Glass ${ }^{13}$ reported LH-RF levels in human plasma and pointed out many problems in the radioimmunoassay, e.g.; rapid inactivation by 
plasma enzymes, loss of immunoreactivity during processing of samples and extremely low concentrations detected in plasma of the women in the reproductive age. The radioimmunoassay system described has several modifications as compared to our other assay system reported since 1973.,5 The first modification was purification of ${ }^{125}$ I-labeled LH-RF by ion CMC column eluted by linear gradient of ammonium acetate buffer. This purification demonstrated that a higher specific activity of radioiodinated LH-RF was obtained by CMC when compared to that by gel filtration through Sephadex G-15 column. The so-called delayed assay in which cold and hot peptides were incubated 48 and 6 hours, respectively, with the same diluted antiserum, was applied for the assay system. This second modification resulted in a higher sensitivity sufficient to detect plasma levels of LH-RF in human subjects. These modifications enabled us to detect as small as $300 \mathrm{fg}$ of LH-RF per tube in the assay system. The specificity of the antiserum utilized in the assay showed less than $0.0001 \%$ displacement by other hypothalamic peptides or by pituitary hormones except analogs of LH-RF with C-terminal. Addition of 2.1 to $500 \mathrm{pg}$ of LH-RF to $1 \mathrm{ml}$ serum treated with charcoal was quantitatively recovered after acid-methanol extraction and mean recovery rate was $96.3 \pm 5.63 \%$. By this newly developed radioimmunoassay, it became clear that plasma LH-RF levels were significantly decreased during pregnancy as compared to those in non-pregnant women. It was also observed that plasma concentration of LH-RF was much higher in menopausal women and further study should be focused on the mechanism of LH-RF release in the women of this age group. Since specific radioimmunoassay of human LHbeta subunit was developed, ${ }^{14,15}$ it has been possible to detect the presence and alteration of pituitary LH in maternal blood. In preliminary study on our hLHbeta subunit radioimmunoassay, the antiserum utilized showed immunologically slight cross-reactivity with hCG. After the antiserum was absorbed with appropriate amount of $\mathrm{hCG}$, the radioimmunoassay system demonstrated significant decrease of serum levels of hLH-beta in pregnant women as compared to those in normal menstrual cycles. Although the values fluctuated but there was no significant increase of hLH-beta subunit during pregnancy. In contrast, a significant peak of hCG was observed around 10 weeks of normal pregnancy after which the hCG values gradually decrease to basal level. This indicates that there is no correlation between serum hCG and LH concentration during pregnancy. Thus LH concentration assayed in the present study does not represent crossreactivity with hCG in our assay system. Our previous findings ${ }^{2}$ and other works 1 demonstrated that the function of LH in the rat is that of maintaining of implanted embryos at an early stage of gestation. The luteotropic function of LH was demonstrated in immunological neutralization of endogenous LH by exogen- 
ously administered antiserum to LH. This resulted in reduction of serum progesterone to non-detectable level and termination of pregnancy by the complete absorption of implanted embryo in pregnant rats. Furthermore specific antiserum to LH-RF has little effect on serum progesterone and fetal development in pregnant rats, ${ }^{2}$ suggesting basal level of $\mathrm{LH}$ can be to some extent maintained in the rats treated with antiserum to LH-RF during early gestation. This tonic level of $\mathrm{LH}$ can maintain progesterone secretion sufficient to develop embryos in this species. From these assay results it can also be inferred that the secretion of pituitary LH in pregnant women is also depressed during pregnancy. Since follicular maturation continues in the human maternal ovary during gestation, ${ }^{16}$ this decreased $\mathrm{LH}$, and presumably $\mathrm{FSH}$ also, may have a role in the follicular development in the maternal gonad but exact physiological role of this hormone in pregnant women remains to be clarified. It should be emphasized that a major role of the hypothalamus and the anterior pituitary gland during gestation is still uncertain, however, it would appear from the present study that the hypothalamo-hypophyseal axis is depressed through gestation in women.

\section{ACKNOWLEDGEMENTS}

The authors wish to thank National Institute of Arthritis, Metabolism and Digestive Diseases for the gift of hLH-beta and hCG-beta assay kits. The authors also feel grateful to Dr. K. Wakabayashi for his generous supply of his second antibody and to Sankyo Pharmaceutical Co. for the gift of synthetic LH-RF.

\section{REFERENCES}

1. Madhwa Raj, H.G. and Moudgal, N. R.: Hormonal Control of Gestation in the Intact Rat. Endocrinology 86: 874-889, 1970

2. Makino, T., Shiina, M., Nakashima, S., et al.: Role of Luteinizing Hormone-Releasing Factor (LH-RF) and LH on Maintenance of Early Gestation in Rats. Endocrinol Japon 24: 83-88, 1977

3. Harris, G. W. and Donovan, B. T.: The Pituitary Gland, Vols. I, II, III. University of California Press, Berkeley 1966

4. Makino, T., Takahashi, M., Yoshinaga, K., et al.: Ovulation Blockade in Rats by Rabbit Anti-Luteinizing Hormone-Releasing Factor Serum. Contraception 8: 133145,1973

5. Makino, T. and Greep, R. O.: Effect of Reserpine and Melatonin on Hypothalamic Content of LH-RF and Ovulation. Abstract of the 55th Annual Meeting of The Endocrine Society, Abstract \#202, 1973

6. Hunter, W. M. and Greenwood, F. C.: Preparation of iodine-131 labeled Human Growth Hormone of High Specific Activity. Nature 194: 495-496, 1962

7. Smith, P.E.: Non-essentiality of Hypophysis for Maintenance of Pregnancy in Rhesus Monkeys. Anat. Rec. 94: 497, 1946

8. Little, B., Smith, O. W., Jessiman, A.G., et al.: Hypophysectomy during Preg- 
nancy in a Patient with Cancer of the Breast; Case Report with Hormone Studies. J. Clin. Endocr. Met. 18: 425-443, 1958

9. Kerdelhué, B. and Jutisz, M.: Development of a Radioimmunoassay of a Hypothalamic Hormone which stimulates the Release of Pituitary LH and FSH (LHRF) using a Synthetic Decapeptide as Antigen. Abstract of the IVth International congress of Endocrinology, Abstract \#352, 1972

10. Nett, T. M., Akbar, A.M., Niswender, G. D., et al.: A Radioimmunoassay for Gonadotropin-Releasing Hormone (Gn-RH) in Serum. J. Clin. Endocrinol. Metab. 36: $880-885,1973$

11. Key, W. R., Kelch, R.P., Jr., Niswender, G. D., et al.: Quantitation of Endogenous and Exogenous Gonadotropin Releasing Hormone by Radioimmunoassay. J. Clin. Endocrinol. Metab, 36: 1263-1267, 1973

12. Fraser, H. M., Jeffcoate, S. L., Holland, D. T., et al.: Detection of Luteinizing Hormone Releasing Hormone in the Peripheral Blood in the Rat on the Afternoon of Pro-estrous. J. Endocrinol. 59: 375-376, 1973

13. Aksel, S. and Glass, R.: Luteinizing Hormone-Releasing Hormone Levels in Human Plasma: A Radioimmunoassay Method. Amer. J. Obstet. Gynecol, 135: 619-623, 1979

14. Hagen, C. and MeNeilly, A. S.: The Gonadotropic Hormones and Their Subunits in Human Maternal and Fetal Circulation at Delivery. Amer. J. Obstet. Gynecol. 121: $926-930,1975$

15. Closset, J., Vandalem, J. L. and Hennen, G.: Human Luteinizing Hormone. Isolation and Characterization of the Native Hormone and its alpha and beta Subunits. Eur. J. Biochem. 57: 325-333, 1975

16. Nelson, W. W., Forks, G. and Greene, R. R.: Some Observation on the Histology of the Human Ovary during Pregnancy. Amer. J. Obstet. Gynecol. 76: 66-90, 1958 